\title{
Necrotizing Fasciitis: Race against Time to Salvage Limb from potential Amputations; a Case Report
}

\author{
${ }^{1}$ National University of Sciences and Technology, Pakistan \\ ${ }^{2}$ University of Health Sciences Lahore, Pakistan \\ ${ }^{3}$ Thomas Jefferson University, Pennsylvania \\ ${ }^{4}$ Dow University of Health Sciences, Pakistan \\ ${ }^{5}$ Ghulam Mohammad Maharashtra Medical College, Pakistan \\ ${ }^{6}$ Fatima Jinnah Medical College for Women Lahore, Pakistan \\ ${ }^{7}$ Hospital Multan, Pakistan \\ ${ }^{8}$ Nishter Medical University, Pakistan \\ ${ }^{9}$ King Edward Medical University, Pakistan \\ ${ }^{10}$ Khyber University, Pakistan \\ ${ }^{11}$ Aga Khan University Hospital, Pakistan
}

Quratulain Fatima Masood ${ }^{1 *}$, Ali Asad ${ }^{2}$, Anika Naeem ${ }^{2}$, Saad Wasiq ${ }^{2}$, Sara Habib ${ }^{3}$, Maira Nusrat ${ }^{2}$, Fnu Sandeep ${ }^{4}$, Umair Hamid ${ }^{2}$, Vinesh Kumar ${ }^{5}$, Aimen Mubashar ${ }^{6}$, Atufa Kaleem ${ }^{7}$, Zainab Khan ${ }^{8}$, Umer Zia ${ }^{2}$, Hafiz Zarsham Ali Ikram $^{10}$, Areej Khan ${ }^{9}$, Atif Ibrahi , Afshan Naz Amray ${ }^{4}$ and Syed Yawar Mehdi ${ }^{11}$

Submission: April 10, 2018; Published: April 17, 2018

*Corresponding author: Quratulain Masood, National University of Sciences and Technology, Karachi, Pakistan, Email: quratulain.fatima@gmail.com

\begin{abstract}
Necrotizing Fasciitis is a rare, rapidly progressive and lethal infection of the soft tissues of the body, which can result in necrosis. Early diagnosis and prompt management with antibiotics and surgical debridement of the affected limb can prevent devastating outcomes. We present a case of a seven year old boy with altered mental status and cellulitis of his right thigh. Astute and rigorous care resulted in preventing limb amputation.
\end{abstract}

Keywords: Necrotizing fasciitis; Prompt treatment

\section{Introduction}

"Flesh eating bacteria" or Necrotizing Fasciitis is a life threatening tissue infection that spreads swiftly. It often presents with local skin changes, fever and vomiting. Limbs and perineum are the most commonly involved infected sites. The major risk factors include a poor immune status, diabetes, cancer, obesity, alcoholism and peripheral arterial disease. Necrotizing Fasciitis is mostly a mono-microbial disease; Group A streptococcus and methicillin resistant staphylococcus aureus being the most common causative agents. The pathophysiology suggests the exotoxin production by bacteria causes necrosis of the tissue, activating immune responses and spreading extensively.

There are various techniques of diagnosing it including the Laboratory Risk Indicator for Necrotizing Fasciitis (LRINEC) scoring system. MRI has a better sensitivity and is the gold standard to diagnose it.

\section{Case Report}

A seven year old boy, was referred to our facility in an altered mental state with a swollen, erythematous right thigh, a rash of the overlying skin for the last three days. The patient was treated at a separate facility by orthopedic surgeon and neuro-physician. The patient was shifted to I.C.U and treated for septic shock. Empiric oral antibiotics and fluid resuscitation were started. Orthopedic consultation was sought, who advised immediate surgery. Intra operatively circumferential debridement of the necrotic skin, subcutaneous tissue and fascia were done. There was significant necrosis of the muscle of right thigh which also needed 
debridement. Extensive debridement was done, extending to the dorsal, ventral and lateral surface of thigh. Pus was drained and washing were sent for culture sensitivity (Figure $1 \& 2$ ). Antibiotic therapy was given for seven days.
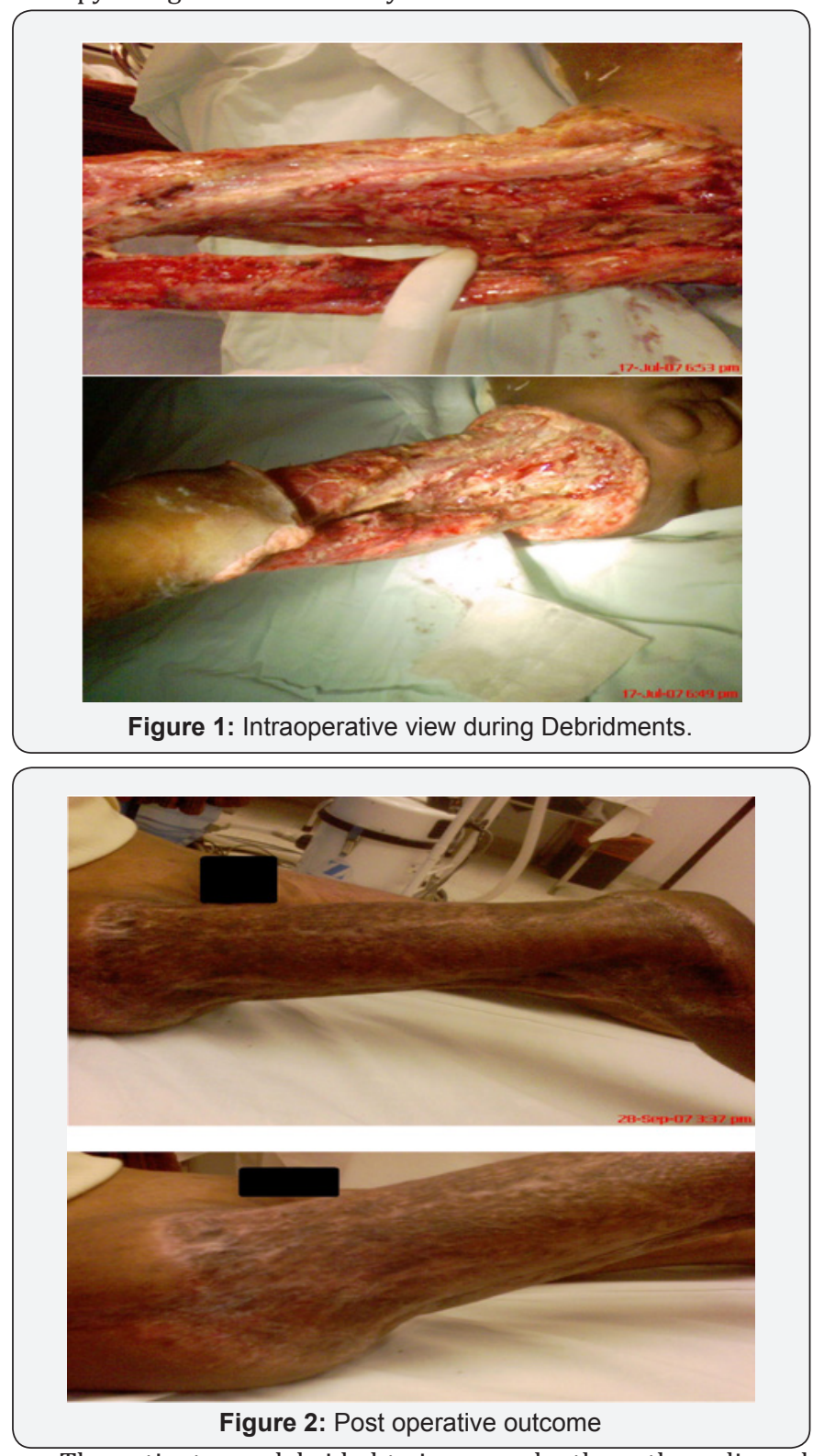

The patient was debrided twice more by the orthopedic and plastic surgery teams. Despite the initial debridement being successful, two successive debridement were done to control the infection and keep the wound clean for better healing. The plastic surgeon recommended a flap cover with skin grafting once the wound was clear. Dressings were continued with regular inspection of the wound [1-6].

The patient was operated again and exposed femoral vessels were covered by transportation on partially debrided but healthy remaining semitendinosus muscle. The exposed muscles of thigh and upper calf were covered with a meshed split skin graft. There were eighty to nighty percent graft taken. Following soft tissue cover showed signs of improved perfusion with good tissue oxygenation and the patient improved exponentially.

\section{Discussion}

Necrotizing Fasciitis is an infection of soft tissues which particularly targets fascia due to its poor blood supply and can cause impairment to muscular function. It manifests with fever, erythema and pain. Sepsis, renal failure and limb loss are complications in adults, with 35 percent mortality rate. Face and extremities are mostly affected in children with mortality rate of 36-88 percent and 5.4 percent in infants and children respectively. Sepsis and limb loss are chief dilemma.

The clinical approach to decrease mortality and morbidity is by early diagnosis using MRI, adequate debridement with extensive support and early wound coverage with local muscle flap as done in our case. Necrotizing Fasciitis is a challenging clinical diagnosis. MRI was found to be convenient in determining the extent of necrotizing fasciitis and accurately predicted necrosis as compared to myoglobinuria, elevated creatine kinase, raised lactate dehydrogenase and other imaging modalities.

Remedy begins with antibiotics but fetid tissue bars antibiotic's invasion. Here regular and rigorous debridement frames strut of treatment. The mortality of this disease has not been altered by antimicrobials. Surgical debridement holds great mortality benefit. $12-48$ hours is the critical period. Surgical debridement done before 12 hours and repeated every 24 hours shows remarkable improvement. Limb amputation becomes mandatory when delay occurs. Delay in surgical debridement also raises the odds of post debridement complications. Revival through plastic surgery aids in recouping form and function of devitalized tissue and rushes its healing process.

Our case explains the expertise of orthopedics and plastic surgery in a joint effort to save the limb and providing an encouraging outcome in a conservative and more rigorous fashion. The surgical technique can be a prototype for surgeons and an academic example where debridement and a flap graft controlled the infection and saved a limb.

\section{References}

1. Gozal D, Ziser A, Shupak A (1986) Necrotizing fasciitis. Jama Surgery.

2. Chelsom J, Halstensen A, Haga T, Høiby EA (1994) Necrotising fasciitis due to group A streptococci in western Norway: incidence and clinical features. Lancet 344(8930): 1111-1115.

3. Zundel S, Lemaréchal A, Kaiser P, Szavay P (2017) Diagnosis and Treatment of Pediatric Necrotizing Fasciitis: A Systemic Review of the Literature. Eur J Pediatr Surg 27(2): 127-137.

4. Kuroda J, Inoue N, Satoh H, Fukuzawa R, Terakawa T (2015) Neonatal Necrotizing Fasciitis of the scrotum caused by Streptococcus Agalactiae. Pediatr Int 57(2): e56-e58.

5. Endorf FW, Garrison MM, Klein MB, Richardson A, Rivara FP (2012) Characteristics, therapies and outcome of children with necrotizing soft tissue infections. Pediatr Infect Dis J 31(3): 221-223.

6. Masood Q (2017) Imaging Studies to diagnose Necrotizing Fasciitis: A Non Invasive Approach for Clinicians. MOJ Surg. 
is work is licensed under Creative Commons Attribution 4.0 License

DOI: 10.19080/JAICM.2018.06.555692
Your next submission with Juniper Publishers will reach you the below assets

- Quality Editorial service

- Swift Peer Review

- Reprints availability

- E-prints Service

- Manuscript Podcast for convenient understanding

- Global attainment for your research

- Manuscript accessibility in different formats

( Pdf, E-pub, Full Text, Audio)

- Unceasing customer service

Track the below URL for one-step submission https://juniperpublishers.com/online-submission.php 